\title{
DAKWAH ADVOKASI KEBIJAKAN \\ (IMPLEMENTASI PERATURAN DAERAH NO.2 TAHUN 2007 DI KECAMATAN SUNGAI TARAB)
}

\author{
Irwandi \\ Dosen IAIN Batusangkar \\ Jln. Sudirman No. 137 Kubu Rajo, Lima Kaum Batusangkar
}

\begin{abstract}
Dakwah Advocacy Policy (Implementation of Local Regulation No.2 of 2007 in Sungai Tarab Subdistrict) Tanah Datar Regency Regulation number 2 of 2007 is stipulated as one effort to realize the desire of local government and society to implement the vision and mission of Tanah Datar Regency especially in improving the practice of religious values to realize the quality of faith and devotion of the people who are famous for the philosophy of Adat Basandi Syarak, Syarak Basandi Kitabullah. Based on the background, Sungai Tarab Subdistrict as one of the areas in Tanah Datar Regency seeks to implement the law with various forms of activities that encourage the implementation of this regulation as well as possible. This research uses Qualitative method. The results show that the Implementation of Local Regulation No. 2 of 2007, especially in Sungai Tarab Subdistrict has been implemented but in the implementation there are still the following things: For Students On Primary And Secondary Education And Bridal Candidates, substantially accompanied by academic script, which contains -those aspects of philosophy, sociology and juridical this is also related to the excavation and assessment of problems and needs of the community so that the problem to be solved by the regional regulation is not accommodated well, the socialization of the implementation of the local regulation is not done well, causing the interpretation different from the implementation of existing regulations so that the quality of implementation of this local regulation is less positive response from the community, on the one hand this regulation is often ignored, funding support from the local government is still not sufficient to support all components or contents from the implementation of the regulation, the Implementation of Perda in Sungai Tarab Sub-District as a whole has been in operation although in reality there are some provisions that exist in the regulation has not been implemented optimally caused by the limitations of Human Resources which become the object of the implementation of the Regional Regulation.
\end{abstract}

Kata Kunci: Peraturan Daerah, Kebijakan Pemerintah dan Organisasi Keagamaan

\section{PENDAHULUAN}

Cemenjak reformasi 1998 bergulir Nemudian disusul dengan amandemen UUD 1945, hubungan pusat dan daerah mengalami perubahan yang signifikan, dari pola yang sentralistik berubah menjadi desentra- listik. Perubahan ini memberikan wewenang kepada daerah untuk mengurus sendiri urusan pemerintahan menurut asas otonomi dan tugas pembantuannya. Penerapan sistem desentralisasi dalam otonomi 
daerah memberikan dampak positif terhadap masyarakat terutama dalam peningkatan kesadaran politik dan dalam proses pembuatan kebijakan publik.

Keberhasilan pemerintah dalam membuat kebijakan tidaklah sematamata hanya didasarkan atas pertimbangan efisien, prinsip ekonomi dan administrasi, akan tetapi harus pula didasarkan pada pertimbanganpertimbangan etika dan moral. Oleh sebab itu, implemetasi kebijakan akan berjalan efektif apabila implementor mengetahui apa yang harus dilakukan. Sangat penting untuk sebuah kebijakan dan instruksi implementasi untuk segera ditransmisikan kepada personel-personel yang tepat sebelum dilaksanakan.

Setiap regulasi yang dikeluarkan baik oleh pemerintah pusat, pemerintah propinsi dan pemerintah kabupaten/kota harus mengacu kepada Pancasila dan UndangUndang Dasar 1945, termasuk regulasi kehidupan beragama di setiap wilayah kesatuan Republik Indonesia. Hal ini tercantum dalam BAB XI Pasal 29 ayat (1) dan ayat (2) UUD 1945 yaitu: ayat (1) negara berdasar atas ketuhanan Yang Maha Esa, dan ayat (2) Negara menjamin kemerdekaan tiap-tiap penduduk untuk memeluk agamanya masing-masing dan untuk beribadat menurut agamanya dan kepercayaannya itu.

Berdasarkan Undang-Undang Dasar 1945 dan UU Nomor 39 tahun 1999 tersebut, regulasi tentang kebebasan beragama diharapkan mampu meningkatkan peran serta masyarakat untuk melaksanakan dan mengamalkan agamanya sesuai dengan tuntutan agamanya, yang berdampak pada pembangunan manusia Indonesia seutuhnya.

Pada tahun 2004 lahirlah Undang-undang Nomor 32 tahun 2004 Tentang Pemerintahan Daerah. Hal ini dipandang sebagai cara untuk mewujudkan secara nyata penyelenggaraan pemerintahan yang efektif, efisien dan beribawa guna mewujudkan pemberian pelayanan kepada masyarakat dalam meningkatkan kesejahteraan otonomi daerah juga merupakan keterikatan yang kuat antara daerah yang satu dengan yang lainnya, disamping menumbuhkembangkan semangat kebersamaan dalam simpul Negara Kesatuan Republik Indonesia (Haw Wijaya, 2003: 32).

Menindaklanjuti UndangUndang Nomor Nomor 32 tahun 2004, lahirlah Undang-Undang Nomor 2 Tahun 1999 Tentang Pemerintahan Daerah. yang bertujuan untuk menyelenggarakan otonomi daerah sepenuhnya ditingkat kabupaten/kota dan tugas pembantuan (medebewind) dalam rangka mengurus kepentingan rakyat setempat menurut prakarsa sendiri berdasarkan aspirasi masyarakat, potensi untuk menyusun regulasi oleh daerah guna diterapkan di daerah.

Peluang perlakuan disentralisasi otonomi daerah memberikan 
kewenangan untuk mengatur dan menyelenggarakan pemerintahan kepada daerah. Penyerahan ini berarti memberikan kesempatan kepada aparat daerah, termasuk dewan perwakilan rakyat untuk berpartisipasi di dalam merencanakan dan melaksanakan berbagai kebijaksanaan pembangunan tanpa harus mendapat arahan dan atau diarahkan oleh pusat (top down atau bottom up).( Haw Wijaya, 2003: 32)

Kebebasan dalam kehidupan beragama dan peluang bagi daerah untuk menentukan arah kebijakkan berdasarkan kearifan lokal mendorong Pemerintah Propinsi Sumatera Barat mengeluarkan Peraturan Daerah Nomor 3 tahun 2007 Tentang Pendidikan al-Qur^an. Hal ini mendorong kabupaten/kota untuk menyusun peraturan daerah yang mengarah pada peningkatan kualitas pembelajaran al-Qur^an hak ini termasuk di Kabupaten Tanah Datar.

Secara historisKabupaten Tanah Datar yang berjulukkan "Luhak Nan Tuo" sampai saat ini tetap mencantumkan Visidan Misi Pembangunannya dengan Filosofi " Adat Basandi Syarak-Syarak Basandi Kitabullah" yang menggambarkan agama Islam yang dianut masyarakat Kab. Tanah Datar diyakini dapat menjadi penggerak pembangunan serta dasar dilahirkannya beberapa peraturan daerah yang berorientasi pada nilainilai agama,
Dari beberapa produk hukum yang di keluarkan oleh Pemerintah Kab. Tanah Datar tahun 2007, salah satu peraturan daerah yang telah disahkan adalah Peraturan Daerah Nomor 2 Tahun 2007 tentang pandai baca tulis al-Qur^an bagi peserta didik pada pendidikan dasar dan menengah dan calon pengantin tanggal 18 Juli 2007, sebelum lahirnya peraturan ini ada beberapa permasalahan yang timbul dalam kegiatan pandai baca tulis al-Qur^an, di antaranya; masih adanya generasi muda yang belum pandai baca tulis al-Quran, belum adanya ketentuan khusus dalam penyelenggaraan pembelajaran baca tulis al-Qur^an pada lembaga pendidikan al-Qur^an, belum jelasnya penanggungjawab lembaga dan penanggungjawab pembinaan, belum adanya ketentuan penyelenggaraan ujian bagi santri yang dikeluarkan oleh lembaga terkait, belum adanya ijazah resmi yang di keluarkan oleh lembaga resmi, belum adanya ketentuan khusus tentang penyelenggaraan pendidikan al-Qur^an di lembaga pendidikan formal dan bagi calon pengantin, masih kurangnya manajemen pengelolaan, masih kurangnya dukungan penuh dari masyarakat, masih kurangnya sarana dan prasarana, belum adanya akreditasi dan sertifikasi TPA dan guru TPA, belum adanya sanksi khusus bagi yang tidak padai baca tulis al-Qur^an

Untuk menjalankan peraturan dimaksud pada tanggal 15 Maret 
2011, telah dikeluarkan Peraturan Bupati Tanah Datar nomor 18 tahun 2011 tentang pedoman pelaksanaan pandai baca tulis al-qur^an bagi peserta didik pada pendidikan dasar dan menengah dan calon pengantin, pada tanggal 21 Maret 2011, lahirlah instruksi Bupati Tanah Datar Nomor 1 Tahun 2011 tentang pelaksanaan peraturan daerah nomor 2 Tahun 2007 tentang pandai baca tulis al-Qur^an bagi peserta didik pada pendidikan dasar dan menengah dan calon pengantin dan peraturan bupati Tanah Datar nomor 18 tahun 2011 tentang pedoman pelaksanaan peraturan daerah nomor 2 tahun 2007 tentang pandai baca tulis al-Qur^an bagi peserta didik pada pendidikan dasar, menengah dan calon penganten.

Instruksi ini di tujukan kepada Kepala Dinas Pendidikan Kabupaten Tanah Datar serta Camat seKabupaten Tanah Datar, sedangkan Kementerian Agama Kabupaten Tanah Datar dalam melaksanakan peraturan daerah ini mengacu kepada peraturan Presiden Republik Indonesia Nomor 63 Tahun 2011 tentang organisasi dan tata kerja instansi vertikal kementerian agama Pasal (15) yang menyatakan semua unsur di lingkungan instansi vertikal kementerian agama dalam melaksanakan tugasnya wajib menerapkan prinsip koordinasi, integrasi, dan sinkronisasi, baik dalam lingkungan instansi vertikal kementerian agama sendiri maupun dalam hubungan antar instansi pemerintah baik pusat maupun daerah.

Semua ketentuan tersebut harus dijalankan oleh seluruh Stokholder terkait, dengan langkah-langkah sebagai berikut; Pertama mensosialisasikan Peraturan Daerah Nomor 2 Tahun 2007 dan Peraturan Bupati Tanah Datar Nomor 18 Tahun 2011 kepada masyarakat dan melibatkan seluruh komponen masyarakat, kedua melakukan inovasi dan langkahlangkah strategis dalam pelaksanaan sesuai Tupoksi masing-masing stockholder dan sesuai dengan ketentuan yang berlaku.

Aplikasi peraturan ini, seyogyanya dilaksanakan di setiap nagari dan kecamatan di Kab. Tanah Datar, dengan berbagai kegiatan yang menunjang kualitas dan kuantitas pelaksanaan pembelajaran baca tulis al-Qur^an. Beberapa kecamatan di Kab. Tanah Datar telah melakukan langkah-langkah untuk percepatan pemberantasan tulis baca al-Quran dengan berbagai program kegiatan, salah satu kecamatan yang telah melaksanakan program tersebut adalah Kecamatan Sungai Tarab.

Pentingnya penerapan Perda Nomor 2 tahun 2007 secara implinsit memberikan harapan kepada masyarakat untuk pelaksanaan pemberantasan baca tulis al-Qur^an di Kabupaten Tanah Datar dengan baik dan benar serta menjadi sarana melahirkan generasi yang berkualitas. 


\section{METODE}

Tipe penelitian ini adalah penelitian kualitatit sebagai pendekatan dasar adalah menemukan "sesuatu" atau "makna" yang dinilai belum diketahui sebelumnya sehingga memerlukan penelitian yang bersifat "grounded" naturalistic, dimana peneliti tidak memberian "pengaruh" atau "intervensi" pada objek penelitian, etnografik, dimana peneliti mempertimbangkan unsur-unsur spesifik dari objek penelitian dan untuk mencapainya peneliti menjadi instrument utama penelitian (Diant Nugroho, 2003:107)

\section{KERANGKA KONSEPTUAL}

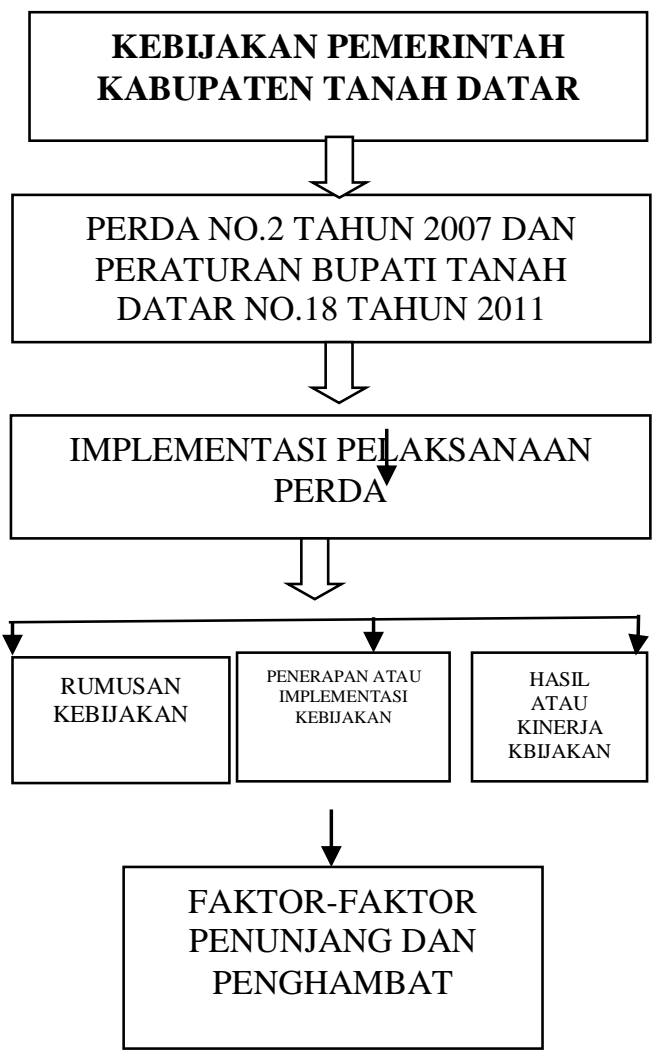

\section{HASIL DAN PEMBAHASAN}

1. Latar Belakang Lahirnya Peraturan Daerah Nomor 2. Tahun 2007 Tentang Pandai Baca Tulis Al-Qur^an Bagi Perserta Didik Pada Pendidikan Dasar dan Menengah Dan Calon Pengantin di Kecamatan Sungai Tarab.

Perumusan peraturan daerah di dasarkan kepada; pertama, Undang-undang nomor 32 Tahun 2004 tentang Pemerintahan Daerah, undang-undang ini memberikan peluang kepada pemerintah daerah baik pada level propinsi maupun kabupaten/kota, kedua, peraturan pemerintah nomor 38 Tahun 2007 tentang pembagian urusan pemerintahan antara pemerintah, pemerintahan daerah provinsi, dan pemerintahan daerah kabupaten/kota.

Berdasarkan kepada undangundang nomor 32 tahun 2004 dan peraturan pemerintah nomor 38 tahun 2007, peraturan daerah yang di bentuk karena ada kewenangan yang dimiliki oleh daerah otonom. Untuk menindaklanjuti hal dimaksud, beberapa peraturan daerah yang ditetapkan oleh pemerintah Kabupaten Tanah Datar, di antaranya adalah peraturan daerah nomor 2 . tahun 2007 tentang pandai baca tulis al-Qur^an bagi perserta didik pada pendidikan dasar dan menengah dan calon pengantin di Kabupaten Tanah Datar. Prosedur penetapan perda tersebut didasarkan pada:

a. Keputusan Menteri Dalam Negeri dan Otonomi Daerah 
Nomor 21 Tahun 2001 tentang teknik penyusunan dan materi muatan produk-poduk hukum daerah.

b. Keputusan Menteri Dalam Negeri Nomor 22. Tahun 2001 tentang bentuk produk-produk hukum daerah.

c. Keputusan Menteri Dalam Negeri Nomor 23 Tahun 2001 tentang prosedur penyusunan produk-produk hukum daerah

d. Keputusan Mendagri nomor 24 tahun 2001 tentang lembaran daerah dan berita daerah.

Berdasarkan hal tersebut, rancangan peraturan daerah tentang baca tulis al-Qur^an di prakasai oleh Kepala Bagian Kesra Setda Kabupaten Tanah Datar dan di bantu oleh Kantor Departemen Agama serta organisasi keagamaan. Rancangan produk hukum dimaksud di ajukan kepada Sekretaris Daerah Kabupaten Tanah Datar, dan Sekretaris Daerah menugaskan Kepala Bagian Hukum untuk melakukan harmonisasi materi dan sinkronisasi pengaturan.

Rancangan peraturan daerah yang diajukan oleh kepala bagian Kesra sebelumnya telah dilakukan pembahasan dengan instansi terkait dan organisasi keagamaan di kabupaten Tanah Datar. Bagian Kesra sebagai pemarkasa lahirnya perda ini telah berupaya untuk menganalisa dampak yang akan terjadi baik secara historis, filosofis maupun sosiologis kalau perda ini ditetapkan.
Keterlibatan masyarakat dalam penyusunan produk hukum terlihat jelas dalam peraturan perundangundangan yang berlaku, yang terwakilkan oleh lembaga-lembaga penyalur aspirasi masyarakat seperti MPR, DPR, DPRD, Orsospol dan BPRN, lembaga ini bekerja sesuai dengan isi Undang-undang Dasar 1945.

Partisipasi masyarakat dalam pembentukan Peraturan perundangundangan dapat diartikan sebagai partisipasi politik, oeh Huntington dan Nelson partisipasi politik diartikan sebagai kegiatan warga Negara sipil (private citizen), yang bertujuan untuk mempengaruhi pengambilan keputusan oleh pemerintah (Iza Rumesten, 2011: 2327)

\section{Implementasi Kebijakan Peraturan Daerah Nomor 2. Tahun 2007}

Implementasi Peraturan Daerah Nomor 2. Tahun 2007 tentang pandai baca tulis al-Quran bagi perserta didik pada pendidikan dasar dan menengah dan calon pengantin diatur dalam Peraturan Bupati Tanah Datar Nomor 18 Tahun 2011 tentang pedoman pelaksanaan peraturan daerah nomor 2. Tahun 2007 tentang pandai baca tulis al-Quran bagi perserta didik pada pendidikan dasar dan menengah dan calon pengantin. Meliputi ; tujuan, kewajiban dan penyelenggaraan pandai baca tulis alQur^an, lembaga pendidikan al- 
Quran, persyaratan lembaga pendidikan al-Qur^an, kurikulum, tenaga pengajar, pengawasan, khatam alQur^an, pembiayaan dan pengelolaan pertanggungjawaban keuangan, calon pengantin dan sanksi

a. Implementasi kebijakan peraturan daerah Nomor :2 tahun 2007 bagi perserta didik pada pendidikan dasar dan menengah di Kecamatan Sungai Tarab.

1).Tujuan, kewajiban dan penyelenggaraan pandai baca tulis al-Qur^an

Tujuan dan kewajiban serta penyelenggaraan pandai baca tulis alQuraan di Kecamatan Sungai Tarab setiap sekolah dasar/madrasah ibtidaiyah, sekolah lanjutan tingkat pertama atau sederajat dan sekolah lanjutan tingkat atas atau sederajat harus menambah jam pelajaran agama diluar jam sekolah yang di pergunakan khusus untuk belajar alQur^an.

Penetapan tujuan, kewajiban dan penyelenggaraan kegiatan pandai baca tulis al-Qur^an diberbagai tingkat sekolah di Kecamatan Sungai Tarab memang sangat berbeda, salah satu bentuk penyelenggaraan kegiatan tersebut adalah dengan penambahan jam pembelajaran al-Qur^an. Penambahan jam pembelajaran tersebut sebagaian besar telah dilaksanakan di sekolah-sekolah di Kecamatan Sungai Tarab

Penetapan tujuan, kewajiban dan penyelenggaraan pandai baca tulis al-Quran di Kecamatan Sungai Tarab di rumuskan dalam bentuk komitmen bersama dibuktikan dengan lahirnya buku panduan penyelenggaraan pendidikan alQur^an di TPQ baik di sekolah maupun di masjid/mushall/surau dan tempat lainnya yang menyelenggarakan pendidikan.

2). Lembaga Pendidikan al-Qur^an (LPA), dan Persyaratan Lembaga Pendidikan al-Qur^an.

Dari 66 buah lembaga pendidikan al-Qur^an yang ada di Kecamatan Sungai Tarab seluruhnya telah terakreditasi dan sudah telah terdaftar di kementerian Agama Kabupaten Tanah Datar. Lembaga Pendidikan ini setiap tahun oleh Kantor Urusan Agama terus di bina.

Pembentukan lembaga pendidikan al-Qur^an di maksud sudah sesuai dengan persyaratan yang di muat dalam Pasal (7), dan khusus untuk MDA disesuaikan dengan Peraturan Perundang-undangan.

Sesuai dengan persyaratan pembentukan TPA/TPSA dan MDA diantaranya; mempunyia santri paling sedikit 20 orang, memiliki sarana prasarana belajar, meiliki struktur kepengurusan dan memiliki guru tetap paling sedikit 1 (satu) orang.

Pada hasil analisa persyaratan pendirian lembaga pendidikan ini belum sepenuhnya diterapkan sesuai yang diharapkan. Berkaitan dengan akreditasi kemampuan guru dan kesediaan TPA masih di dapatkan hasil temuan sebagai berikut: kependidikan guru yang belum memadai, kemampuan guru yang 
belum teruji secara baik sesuai dengan standar yang diharapkan, jumlah santri yabelum ditetapkan sebagai dasaar penetapan suatu lembaga pendidikan al-Qur^an, dan administrasi dan dukungan masyarakat yang masih lemah.

3). Kurikulum

Dalam pelaksanaan kegiatan pembelajaran baca tulis al-Qur^an di Kecamatan Sungai Tarab, telah di keluarkan kurikulum pandai baca tulis al-Quran yang berlaku untuk semua TPA/TPSA yang ada di Kecamatan Sungai Tarab, kurikulum dimaksud di sampaikan dalam bentuk buku dan di sosialisasikan dalam bentuk pelatihan-pelatihan yang di adakan oleh Kantor Urusan agama Kecamatan Sungai Tarab, namun dalam pelaksanaannya masih mengalami kendala.Kendala-kendala tersebut terlihat dari segi pemahaman terhadap kurikulum, langkah-langkah pelaksanaan dan dukungan dari pihak lembaga pendidikan al-Qur^an yang ada.

4). Persyaratan Lembaga Pendidikan al-Qur^an

TPA/TPSA belum sepenuhnya menerapkan manajemen administrasi yang baik. Apalagi di kaitkan dengan akreditasi kemampuan guru TPA/TPSA dan kesediaan TPA/TPSA yang meliputi; kependidikan guru, kemampuan guru, jumlah santri, administrasi serta dukungan masyarakat

5). Tenaga Pengajar
Dari hasil temuan masih adanya tenaga pengajar yang mempunyai kualitas rendah, karena sebagian tenaga pengajar berasal dari pendidikan non agama, bahkan tidak pernah menempuh jalur pendidikan agama,

6). Pengawasan

Pengawasan

yang dilaksanakan oleh kementerian agama Kab. Tanah Datar dalam bentuk peninjauan langsung ke lokasi pelaksanaan kegiatan TPA dan penerimaan laporan tertulis dari seluruh penyuluh agama yang ada di Kecamatan, pengawasan ini perlu dilaksanakan untuk meninjau sejauh mana pelaksanaan Peraturan daerah ini berjalan sesuai yang diharapkan, memang diakui pengawasan yang dilaksanakan belum maksimal karena keterbatasan anggaran pelaksanaan kegiatan

7). Khatam al-Qur^an

Khatam al-Qur^an merupakan salah satu tradisi dalam kegiatan pembelajaran al-Qur^an khususnya di Kecamatan Sungai Tarab. Kegiatan ini bertujuan untuk mengukur kemampuan peserta didik dalam menempuh pendidikan Al-Qur^an di lembaga pendidikan al-Qur^an.

Khatam al-Qur^an juga merupakan serangkaian kegiatan yang dilaksanakan oleh pengurus LPA beserta masyarakat setempat untuk para santri yang lulus seleksi dalam rangka menamatkan pendidikannya di LPA dan sekaligus sebagai tanda untuk memasuki dunia pendidikan 
formal yang telah di amanatkan dalam Peraturan Daerah.

8). Pembiayaan

Banyak persoalan yang di hadapi satuan pendidikan yang berkaitan dengan biaya/dana pendidikan, seperti tersedianya sumber dana yang terbatas, rendahnya anggaran yang ditujukan untuk pendidikan, pembiayaan program yang serampangan, kurangnya bantuan pemerintah akibat otonomi daerah, dll. Untuk mengatasi persoalan yang terkait dengan biaya/dana pendidikan, strategi kepala TPA/TPSA diperlukan, guna menggali dana dari berbagai sumber untuk memenuhi kebutuhan biaya pendidikan.

9). Pengelolaan Pertanggungjawaban keuangan

Penggelolaan dan pertanggungjawaban terhadap pengelolaan TPA/TPSA/MDA di Kecamatan Sungai Tarab masih dalam menggunakan pembukuan yang berbentuk sederhana, hal ini, dikarenakan oleh beberapa hal diantaranya, bentuk pengelolaan keuangan yang belum ditentukan oleh Pengurus masing-masing TPA, ketersediaan sumber daya manusia dalam mengelola keuangan

\section{0). Sanksi}

Sanksi yang telah diterapkan di Kecamatan Sungai Tarab untuk peserta didik yang belum pandai baca tulis al-Qur^an adalah dengan membuat surat perjanjian yang ditanda tangani oleh orang tua calon murid/siswa, dengan tenggang waktu selam 6 bulan dan siap memberikan laporan hasil pelaksanaan ke guru agama.

\section{b. Implementasi Kebijakan Peraturan Daerah Nomor 2. Tahun 2007 bagi calon pengantin di Kecamatan Sungai Tarab. \\ Pelaksanaan tes kemampuan} baca tulis al-Quran tetap menjadi prioritas utama dalam rangka mendukung pelaksanaan peraturan daerah Kab. Tanah Datar tentang pandai baca tulis al-Qur^an.

\section{Kinerja kebijakan Peraturan} Daerah Nomor 2. Tahun 2007 Tentang Pandai Baca Tulis AlQur^an Bagi Perserta Didik Pada Pendidikan Dasar dan Menengah Dan Calon Pengantin di Kecamatan Sungai Tarab.

Kinerja suatu kebijakan tidak akan terlepas dari manajemen yang diartikan sebagai proses penggunaan sumber daya organisasi dengan menggunakan orang lain untuk mencapai tujuan organisasi secara efisien dan efektif. Dengan pemahaman tentang kinerja dan manajemen di atas dapat dikatakan bahwa pada hakekatnya menajemen kinerja adalah tentang bagaimana kinerja dikelola. Dasar untuk melaksanakan menajemen kinerja adalah perumusan tujuan, terdapatnya konsesus dan kerjasama, sifatnya 
berkelanjutan, terjadi komunikasi dua arah dan terdapat umpan balik.

Berkaitan dengan hal tersebut di atas untuk melihat kinerja kebijakan Perumusan Peraturan Daerah Nomor 2. Tahun 2007 tentang pandai baca tulis al-Qur^an bagi peserta didik pada pendidikan dasar dan menengah dan calon pengantin di kecamatan sungai tarab.

a. Kinerja Kesiapan implementasi Peraturan Daerah

Berdasarkan intruksi Bupati Tanah Datar Nomor 1. Tahun 2011 tanggal 21 Maret 2011 unsur pelaksana dalam peraturan ini adalah Kepala dinas pendidikan Kab. Tanah Datar dan Camat se-Kab. Tanah Datar. Instruksi ini tidak terlepas dari kegiatan teknis bidang keagaamaan yang di kelola oleh Kementerian Agama Kab. Tanah Datar, namun dalam pelaksanaannya masih ditemui kendala baik kendala teknis maupun non teknis

b. Program Kegiatan

Program kerja yang disusun oleh lembaga taman pendidikan alQuran di kecamatan Sungai Tarab masih dalam bentuk sederhana dan Lahirnya interuksi ini berdasarkan hasil analisa yang di lakukan oleh Bagian Kesejahteraan Rakyat setda Tanah Datar serta mencermati literatur dan turunan dari peraturan di maksud pada tanggal 21 unsur pelaksana dalam pelaksanaan Peraturan Daerah di maksud unsur pelaksana secara teknis di bebankan kepada Kementerian Agama Kab.
Tanah Datar dalam berbagai bentuk sesuai dengan Target pelaksanaan

4. Faktor-faktor pendukung dan penghambat Implentasi Peraturan Daerah Nomor 2. Tahun 2007 Tentang Pandai Baca Tulis alQur^an Bagi Perserta Didik Pada Pendidikan Dasar dan Menengah Dan Calon Pengantin di Kecamatan Sungai Tarab.

Implementasi

peraturan Daerah Kab. Tanah Datar dimaksud tidak akan terlepas dari faktor-faktor pendukung dan penghambat pelaksanaan kegiatan, faktor-faktor inilah yang akan memberikan gambaran terhadap hasilimplementasi penerapan Peraturan Daerah dimaksud.

a. Faktor-faktor pendukung

Implementasi peraturan Daerah Kab. Tanah Datar dimaksud tidak akan terlepas dari faktor-faktor pendukung dan penghambat pelaksanaan kegiatan, faktorfaktor inilah yang akan memberikan gambaran terhadap hasilimplementasi penerapan Peraturan Daerah dimaksud.

1). Analisa Lingkungan Internal, terdiri dari Visi dan Misi Pemerintah daerah dalam meningkatkan kehidupan beragama,Adanya komitmen pemerintah Daerah untuk meningkatkan kualitas dan kuantitas kegiatan, dan pengamalan agama secara baik dan benar oleh masyarakat, Adanya hubungan harmonis 
antara organisasi keagamaan dengan pemerintah daerah, Hubungan yang harmonis antra eksekutif dan legislative, Adanya komitmen pemerintah daerah dalam membangun nilai-nilai religi, Tersedianya lembaga dan instutusi dalam rangka mengembangkan nilai-nilai keagamaan, Tingginya komitmen pemerintah daerah dalam mensejahterakan masyarakat, Dana yang tersedia dalam APBD Kabupaten Tanah Datar

2). Analisa Lingkungan Eksternal terdiri dari; Adanya kebijakan pemerintah pusat yang berorientasi kepada perwujudan tata kelola pemerintahan yang baik (good governace), Adanya kebijakan pemerintah daerah memberikan kesempatan kepada organisasi keagamaan dan kemasyarkatan untuk mengembangkan diri kearah yang lebih baik, Tingginya komitmen pemerintah untuk mewujudkan pemerintahan yang bersih dari kolusi, korupsi dan nepotisme, Secara historis masyarakat Tanah Datar terkenal dengan masyarakat Religius yang menjunjung tinggi nilai-nilai Agama dan Adat Istiadat yang ditandai dengan lahirnya Filosofi ABS-SBK

b. Faktor-faktor Penghambat terdiri dari : Kurangnya Sumber Daya Manusia, Keterbatasan Dana, kurangnya Sosialisasi Kegiatan, . Terbatasnya infrastruktur.

\section{KESIMPULAN}

Dari urian di atas dapat isimpulkan sebagai berikut

1. Peraturan Daerah Kabupaten Tanah Datar Nomor: 2 Tahun 2007 tentang pandai baca tulis al-quran bagi peserta didik pada pendidikan dasar dan menengah dan calon pengantin, secara substansi disertai dengan naskah akademik, yang berisikan hal-hal yang aspek-aspek filosofi, sosiologis dan yuridis hal ini juga berkaitan dengan pengggalian dan pengkajian masalah dan kebutuhan masyrakat sehingga persoalan yang ingin dipecahkan dengan lahirnya peraturan daerah ini kurang terakomodir dengan baik.

2. Sosialisasi pelaksanaan perda dimaksud kurang dilakukan dengan baik sehingga menimbulkan penafsiran yang berbeda dalam menjalankan peraturan yang ada sehingga kualitas pelaksanaan peraturan daerah ini kurang mendapat respon positif dari masyarakat, disatu sisi PERDA ini sering di abaikan.

3. Dukungan dana dari pemerintah daerah masih di rasa belum mencukupi untuk menunjang seluruh komponen atau subsantsi isi dari pelaksanaan peraturan dimaksud.

4. Pelaksanaan Perda di Kecamatan Sungai Tarab secara keseluruhan telah berjalan walaupun pada kenyataannya ada beberapa ketentuan yang ada dalam 


$$
\begin{aligned}
& \text { peraturan tersebut belum } \\
& \text { dilaksanakan secara optimal di } \\
& \text { akibatkan oleh keterbatasan } \\
& \text { sumber daya manusia yang } \\
& \text { menjadi objek pelaksanaan } \\
& \text { peraturan daerah. }
\end{aligned}
$$

\begin{tabular}{|c|}
\hline $\begin{array}{l}\text { Terancam-Punah, } \\
\text { Mutiara Sumber } \\
\text { 2007),cet I. }\end{array}$ \\
\hline 2010, Cet II 2010. \\
\hline
\end{tabular}

\section{DAFTAR PUSATAKA}

\section{Ade Suerani, Dasar-Dasar Pertimbangan Pembentukan Peraturan Daerah http://www.slideshare.net/adesuerani /dasardasar-pembentukan-perda}

Amir MS. Tonggak Tuo Budaya Minang, (Jakarta : Karya Indah, 1987). Cet I.

Duski samad, Syekh Burhanuddin dan Islamisasi di Minangkabau (Jakarta:

TMF Pres. 2002) cetakan II,

Edison dan Nasrun, Tambo Minangkabau Budaya dan Hukum adat di Minangkabau,

(Bukittinggi:

Multimedia, 2010), Cet .I

Haris Herdiansyah, Metodologi Penelitian Kualitatif, (Jakarta Selatan, Salemba Humanika, 2012), Cet. 3

Instruksi Bupati Tanah Datar Nomor 1 Tahun 2011 Tentang Pelaksanaan Peraturan

Daerah Nomor 2 Tahun 2007 dan Pedoman Pelaksanaan Perda Nomor 2 tahun 2007 .
Mohm. Kasiram, Metodologi

Penelitian Kualitatif-kuantitatif, UIN-Maliki Press,

Muhammad Thahi Azhary, Negara Hukum, (Jakrata: Kencana Prenada Group, 2003) Cet.

$$
\mathrm{Ke}-3
$$

Peraturan Bupati Tanah Datar nomor 18 Tahun 2011 Tentang Pedoman Pelaksanaan Pandai Baca Tulis Al-Qura Bagi Peserta Didik Pada Pendidikan Dasar Dan Menengah Dan Calon Pengantin, Berita Daerah

Kab. Tanah Datar Tahun 2011 nomor 5 Seri E

Peraturan Daerah Kabupaten Tanah Datar, Tentang Pandai Baca Tulis Al-Qura Bagi Peserta Didik Pada Pendidikan Dasar Dan Menengah Dan Calon Pengantin, Lembaran Daerah Kab. Tanah Datar Tahun 2007, Nomor 1. Seri E

Victor J. Sedubun, Kajian Filsafat Hukum Jurnal Sasi Vol.16. No.3 Bulan Juli - September 2010 